\title{
PENINGKATAN KOMPETENSI GURU AGAMA ISLAM MELALUI PEMBELAJARAN PENGAMALAN
}

\author{
Nurwahdan \\ IAIN Syekh Nurjati Cirebon \\ nurwahdan_08@yahoo.com
}

\begin{abstract}
This study aims to describe the increasing competence of Islamic and senior high school Islamic religion teachers in Cirebon, Indramayu, Majalengka and Kuningan (Ciayu Majakuning) Regencies. Islamic religious teacher competencies are skills, skills, or skills that meet quality standards. Proportionally Islamic religion teachers teach in the KI-1 and KI-2 regions, apparently in the field they prioritize KI-3. KI-1, KI-2 is the spirit of Islamic religious education. Therefore the religious students are good, but their religiosity has not been successful, because of that their competency needs to be improved. This research uses a qualitative approach. The method used is the research and development ( $R$ and $D)$ method. The results showed that: (1) Based on the results of the analysis of the planning documents, learning process, and evaluation, that the competence of Islamic Religion Teachers of SMA and SMK Kaba Ciayumajakuning Regency was in accordance with the State Minister's Regulation PAN \& RB No. 16 of 2009, has fulfilled Pedagogic, Personality, Social and Professional Competencies well. (2) Procedures for increasing the competence of Islamic religious high school and vocational high school teachers in Ciayumajakuning Regency, using assessment instruments in the form of reports and evaluations of classroom / subject teacher competency assessments. Permendiknas No. 16/2007. The assessment instrument consists of four (4) domains of competency into fourteen (14) competencies, and developed into seventy eight (78) indicators for subject teachers.
\end{abstract}

Keywords: Teacher Competency, experiential learning

\begin{abstract}
Abstrak
Penelitian ini bertujuan untuk mendeskripsikan peningkatan kompetensi guru agama Islam SMA dan SMK di Kabupaten Cirebon, Indramayu, Majalengka dan Kuningan (Ciayu Majakuning). Kompetensi guru agama Islam adalah kemahiran, kecakapan, atau keterampilan yang memenuhi standar mutu. Secara proporsional guru agama Islam mengajar pada wilayah KI-1 dan KI-2, ternyata dilapangan lebih mengutamakan KI-3. KI-1, KI-2 itu sebagai ruh pendidikan agama Islam. Oleh sebab itu siswa keagamaannya bagus, tetapi keberagamaannya belum berhasil, karena itu perlu ditingkatkan kompetensinya. Penelitian ini menggunakan pendekatan kualitatif. Adapun metode yang digunakannya adalah metode research and development $(R$ and $D)$. Hasil penelitian menunjukkan bahwa : (1) Berdasarkan hasil analisis dari dokumen perencanaan, proses pembelajaran, dan evaluasi, bahwa kompetensi Guru Agama Islam SMA dan SMK Kabaupaten Ciayumajakuning, sesuai Permenneg PAN \& RB No. 16 tahun 2009, telah memenuhi Kompetensi Pedagogik, Kepribadian, Sosial, dan Profesional dengan baik. (2) Prosedur peningkatan kompetensi guru agama Islam SMA dan SMK Kabaupaten Ciayumajakuning, menggunakan instumen penilaian berupa laporan dan evaluasi penilaian kompetensi guru kelas/mata pelajaran. Permendiknas No. 16/2007. Instrumen penilaian tersebut terdiri dari empat (4) ranah kompetensi menjadi empat belas (14) kompetensi, dan dikembangkan menjadi tujuh puluh delapan (78) indikator bagi guru mata pelajaran.
\end{abstract}

Keywords: Kompetensi Guru, Pembelajaran Pengalaman 


\section{Pendahuluan}

Kompetensi guru agama Islam adalah kemahiran, kecakapan atau keterampilan yang memenuhi standar mutu. Secara proporsional guru agama Islam mengajar pada wilayah KI-1 dan KI-2, ternyata di lapangan lebih mengutamakan KI-3. KI-1, KI-2 itu sebagai ruh (core) pendidikan agama Islam. Oleh sebab itu siswa keagamaannya bagus, tetapi keberagamaannya belum berhasil, karena itu perlu ditingkatkan kompetensi Gurunya.

Guru merupakan pekerjaan yang memerlukan keahlian khusus (Suprihartiningrum, 2013). Guru sebagai sub sistem pendidikan memiliki level yang berbeda dibanding dengan pekerjaanpekerjaan lain. Level guru tersebut menjadi takaran, "tinggi rendahnya pengakuan profesionalisme terutama sangat tergantung kepada keahlian dan tingkat pendidikan yang ditempuhnya (Dharma, 2005). Secara sederhana pekerjaan yang bersifat profesional adalah pekerjaan yang hanya dapat dilakukan oleh mereka yang secara khusus telah dipersiapkan untuk itu, "bukan pekerjaan yang dilakukan oleh sembarang orang".

Pekerjaan guru agama Islam perlu ditunjang dengan penguasaan kompetensi secara utuh, seperti disiplin ilmu, dan profesionalalisme. Komptensi tersebut tidak mungkin muncul secara tiba-tiba, melainkan melalui proses dengan tahapan yang sitematis. Guru sebagai tenaga profesional tugas utama mendidik, mengajar, membimbing, mengarahkan, melatih, menilai dan mengevaluasi peserta didik pada jalur pendidikan formal (Danim, 2010). Mendidik yang dilaksanakan oleh guru pada dasarnya adalah proses perubahan tingkah laku, dan sebagai suatu hasil pengalaman" (Dahar, 2011). "Tugas utama akan efektif jika guru memiliki kualitas kinerja, derajat profesionalitas tertentu yang tercermin dari kompetensi, kemahiran, kecakapan, atau keterampilan yang memenuhi standar mutu atau norma etika tertentu (Danim, 2010).

Kesulitan pengukuran kompetensi guru tidak hanya pada aspek kompetensi akademik, melainkan juga pada aspek normative sebagaimana pendapat Al Ghazali bahwa barang siapa yang bertugas sebagai guru (pengajar), berarti dia telah menjalani urusan yang besar, oleh karena itu hendaklah ia memelihara etika, bersikap lurus, dan memberi nasihat, mengikuti perbuatan itu lebih kuat dari pada mengikuti perkataan. Pendidikan berkaitan dengan nilai, dan pembentukan karakter manusia.

Keterkaitan ini terutama dengan profil kompetensi guru sebagai pendidik. Profesi guru agama Islam memiliki tugas dan fungsi ganda, ia harus memiliki kecapakan formal dan kompetensi sebagai pendidik dan pengajar di sekolah. Kecakapan formal guru meliputi kualifikasi akademik dan kompetensi, sertifikat pendidik, sehat jasmani dan rohani, serta memiliki kemampuan untuk mewujudkan tujuan pendidikan nasional. Dalam hal ini dapat dikemukakan salah satu tugas pokok dan fungsi guru yang paling mendasar adalah memiliki pengetahuan yang cukup untuk merumuskan tujuan pembelajaran dan pengalaman untuk menerapkan dalam proses kegiatan pembelajaran di kelas. Sebagaimana dinyatakan bahwa guru berkewajiban merencanakan, melaksanakan proses pembelajaran yang bermutu, meningkatkan dan mengembangkan kualifikasi akademik dan kompetensi secara berkelanjutan, objektif, menjunjung tinggi peraturan, undangundang, hukum dan kode etik guru, 
memupuk persatuan dan kesatuan (Arifin, 2007).

Karena itu untuk menyajikan profil guru bermutu adalah Keutuhan profil guru dapat dikonstruksi dari ciri dasarnya, yaitu: a) guru kompeten mengajar bidang studi yang diajarkan; b) guru profesional dalam melaksanakan tugasnya; c) guru terampil melaksanakan tugas kesehariannya (Arifin, 2007). Akar permasalahan yang pasti dan harus dianalisis adalah rangkaian kegiatan dan proses pembelajaran yang merupakan komponen satu sama lainnya saling berkaitan.

Berdasarkan hasil survey di lapangan, ternyata masih beragam pola pengajaran pendidikan agama Islam yang disampaikan oleh GAI, "Lembaga Pendidikan dan Pembinaan Guru di Perguruan Tinggi menyelenggarakan program pengadaan tenaga kependidikan dan diidentifikasi sebagai Lembaga Pendidikan Tinggi Kependidikan (LPTK), belum menyentuh untuk membangun peningkatan kompetensi GAI dari mulai perencanaan, proses pengajaran, perkuliahan dan evaluasi.

Hampir semua komptensi yang dimiliki oleh GAI masih perlu peningkatan yang serius, baik kompetensi pedagogis, sosial, kepribadian maupun kompetensi profesional.

Peningkatan kompetensi GAI adalah sebagai upaya menghasilkan pola pembelajaran PAI pada semua tingkat dan jenjang pendidikan. Undang-undang Sisdiknas membatasi kompetensi guru pada empat kompetensi, yaitu: kompetensi pedagogis, sosial, kepribadian dan profesional. Secara empiris di lapangan kegiatan untuk mengontrol tingkat kompetensi GAI belum dilaksanakan secara optimal, hal ini disebabakan beberapa indikator yang belum jelas, dan berdampak terhadap kinerja guru itu sendiri. Misalnya, keterukuran daya serap, target pencapaian, alat evaluasi, serta pencapaian target mata pelajaran PAI dengan demikian membutuhkan: pertama, tujuan pembelajaran yang tepat dan terukur, kedua, materi yang relevan dengan karakteristik anak didik, ketiga, metode pembelajaran yang merangsang gairah belajar, keempat, alat evaluasi yang terukur.

Berdasarkan uraian di atas, maka dibutuhkan takaran sebagai alat ukur tes kompetensi GAI, dalam melakukan penilaian Kompetensi GAI sekurangkurangnya dibutuhkan dua instrumen, yaitu: Instrumen Penilaian Kompetensi Guru PAI 1 (IPKG PAI 1) dan Instrumen Penilaian Kompetensi Guru PAI 2 (IPKG PAI 2). Instrumen Penilaian Kompetensi Guru GAI 1 (IPKG PAI 1) merupakan rencana pelaksanaan pembelajaran (RPP) yang menjadi skenario pembelajaran yang disiapkan guru sebelum masuk kelas.

Hal ini perlu perhatian mendalam tentang perbedaan materi agama Islam dan metodologi pengajaran agama Islam bagi GAI. Agama Islam menitik beratkan pada sejumlah pengamalan kaitannya dengan pembentukan karakter yang baik, tetapi tidak meninggalkan pentingnya ilmu dan filsafat. Dengan kata lain, pembelajaran agama saling bersinggungan atau keterkaitan dengan ilmu, dan filsafat. Cara memperoleh ilmu dengan metode ilmiah, filsafat dengan berpikir kritis, cara memperoleh agama dengan tahanuts. Fokus agama banyak bermuara pada olah hati menghasilkan tanggung jawab dan ikhlas.

Landasan materi pembelajaran agama Islam di antaranya bersumber pada Q.S Al-Alaq ayat 1 yaitu "Iqra". Ayat ini bukan hanya sekedar membaca secara 
tersurat, melainkan mengandung arti tersirat. Maksudnya, selain membaca atau meneliti potensi (kemampuan) diri sendiri (beragama) juga meneliti dunia luar (alam semesta) sebagai sumber materi pembelajaran Agama Islam. Akan tetapi, kenyataan menunjukkan orang lebih melihat ke luar dari pada ke dalam jiwanya. Jika saja manusia mau menakar dirinya, maka ia dapat menghitung dan menimbang dirinya seberapa besar porsi otak, jantung, dan rasa mendominasi dirinya untuk berpikir (Wahidin, 2015). Pada umumnya mayoritas orang tidak mengetahui potensi rubbubiyah (iman) yang ada pada dirinya sehingga mengakibatkan orang lupa diri.

Berdasarkan observasi di lapangan, bahwa guru agam Islam dalam proses kegiatan belajar mengajar baru mengajarkan pengetahuan agama Islam. sedangkan pada hakikatnya agama adalah jalan, untuk menempuh jalan tersebut alatnya adalah Syariat. Syariat dalam ajaran Islam yaitu; (1) Syahadat, (2) Sholat, (3) Zakat, (4) Puasa, dan (5) Hajji. Adapun Syariat Islam yang dapat dikerjakan selama proses kegian belajar mengajar (KBM) adalah dalam bentuk ibadah, yaitu; dimulai dari berwudlu, shalat, tadarus, zdikir, dan do'a.

Berdasarkan uraian di atas, penulis mengangkat masalah dalam penelitian ini dengan judul:

Peningkatan Kompetensi Guru Agama Islam Melalui Pembelajaran Pengamalan (Penelitian tentang Komptensi Pedagogis, Komptensi Profesional, Komptensi Kepribadian dan Komptensi Sosial Guru Pendidikan Agama Islam SMA/SMK di Kabaupaten Ciayumajakuning).

\section{Metode}

Metode penelitian yang digunkan adalah pengembangan model research and development ( $R$ and $D$ ), dengan tahapantahapan gradual penelitiannya sebagai berikut:

a. Research and information collection (includes review of literature),

b. Planning,

c. Develop preliminary form of product,

d. Preliminary field testing,

e. Main product revision,

f. Main field testing,

g. Operational product revision,

h. Operational field testing,

i. Final product revision,

j. Dissemination and implementation.

Sumber data tentang Komptensi GPAI SMA di Wilayah Ciayumajakuning adalah: Pertama menurut konsep ideal berlandaskan pasal 3 UU No. 20 th 2003 tentang Tujuan Pendidikan Nasional, UU No. 14 th. 2005 tentang Guru dan Dosen yang diimplementasikan dalam Peraturan Pemerintah, Permendiknas No. 059 th. 2014 tentang Kurikulum SMA/SMK, alat ukur uji kompetensi guru untuk memperoleh sertifikat sertifikasi guru, termasuk di dalamnya GPAI. Kedua data empirik yang bersumber dari beberapa kajian hasil penelitian tentang Kompetensi GPAI secara holistik.

\section{Hasil dan Pembahasan}

Dokumen Perencanaan Program Pembelajaran (RPP) PAI SMA dan SMK

\section{Ciayumajakuning}

Komponen yang harus diperhatikan dalam rencana program pembelajaran adalah merumuskan tujuan pembelajaran, 
materi atau bahan ajar, metode, media dan evaluasi. Di bawah ini merupakan pengejawantahan dari kompetensi yang tertuang dalam dokumen kurikulum nasional. Selanjutnya menjadi prasyarat bagi guru yang ditugaskan untuk melaksanakan kegiatan belajar mengajar (KBM) di kelas untuk mengembangkan ke dalam model rencana program pembelajaran (RPP).

Dari rumusan indikator pencapaian kompetensi (IPK) di atas yang menjadi kata kunci keberhasilan tujuan pembelajaran, sebab indikator tersebut merupakan sinyal yang memberi peluang kepada guru untuk melahirkan tujuan pembelajaran yang sesuai dengan karakter bahan ajar. Dokumen di atas merupakan aturan yang sudah terprogram dalam permendiknas, pola regulasi yang baku, tetapi manakala kompetensi guru mampu mengembangkan lebih luas dan dalam dari segi kedalaman dan keluasan essensi materi sebagai pengembangan ilmu pengetahuan menuju teori ilmu. Dalam kontek agama berujung pada pengamalan menuju kesolehan atau karakter.

Komponen yang harus diperhatikan dalam rencana program pembelajaran berikutnya adalah merumuskan tujuan pembelajaran, di bawah ini merupakan rumusan tujuan pembelajaran berdasarkan indikator pencapaian kompetensi.
Komponen rumusan tujuan pembelajaran dari sebelas rumusan tujuan pembelajaran apabila diukur menggunakan model Audience, Behavior, Conditioning dan Degree, (A, B, C, dan D) menggunakan kata operasional sebagai rumusan yang melahirkan behavior. Rumusan tersebut menggunakan kata operasional menerima, meyakini, memilih, membangun, menunjukkan, menjelaskan, menyebutkan, diambil dari taksonomi Bloom, selanjutnya dalam rumusan tujuan di atas condition belum muncul secara eksplisit (tidak nampak dengan jelas) karena condition akan melahirkan metode

Dalam konteks rumusan tujuan yang paling essensi adalah penggunaan kata operasional, tujuan yang jelas dan target pencapaian materi ajar. Dalam rumusan tujuan pembelajaran di atas secara eksplisit belum nampak target dan sasaran materi yang jelas. Dengan tidak munculnya target maka tujuan pembelajaran menjadi bias. Ketidakjelasan target dalam rumusan tujuan pembelajaran mengakibatkan kesulitan dalam merumuskan komponen pembelajaran berikutnya.

Gambaran rumusan tujuan di atas merupakan bagian dari kompetensi guru agama, menetapkan tujuan pembelajaran yang tepat adalah bagian dari profesionalisme guru agama. Tujuan merupakan bagian komponen yang sangat 
penting karena tujuan pembelajaran akan memberikan arah sasaran pencapaian bahan ajar. Tujuan hendaknya mampu menjawab permintaan pilosofi materi yang diajarkan, materi ajar sebagai suatu kebutuhan peserta didik. Pada wilayah ini guru profesional dapat mentransfer bahan ajar sesuai kaidah mata pelajaran. Tujuan pembelajaran harus spesifik, yakni tujuan yang tidak bermakna ganda atau multi tafsir, mengandung kejelasan secara konotatif atau denotatif. Salah satu contoh diatas misalnya: "Menyimpulkan hikmah beriman kepada malaikat Allah SWT", hal yang sulit diukurnya adalah pada kata "hikmah" karena jumlah hikmah beriman itu jumlahnya lebih dari satu, maka perlu target yang jelas, apakah 3 atau 4 hikmah beriman kepada malaikat. Begitu juga jumlah malaikat itu banayak, yang lebih pasti adalah salah satu atau lebih hikmah beriman kepada salah satu malaikat. Kemudian akan lebih sesuai dengan kaidah agama apabila dikaitkan dengan pengamalan.

Komponen yang harus diperhatikan dalam rencana program pembelajaran berikutnya adalah merumuskan materi pembelajaran, di bawah ini merupakan rumusan materi pembelajaran berdasarkan indikator pencapaian kompetensi.

Proses Pembelajaran PAI SMA Data Visual (Rekaman) Pembelajaran
Data di bawah ini mendukung dokumen perencanaan yang telah dipaparkan di atas, selanjutnya proses pembelajaran atau jalannya kegiatan belajar mengajar menggambarkan seluruh kompetensi guru agama dalam pelaksanaan tugasnya. Kegiatan proses belajar mengajar merupakan bagian inti dari tugas utama sebagai guru agama Islam. Implementasi dari rencana pembelajaran terakumulasi dalam kegiatan proses belajar mengajar.

Terjadi dialog dalam pertemuan antara guru dan siswa. Ketika guru menyuruh mengacungkan tangan, siswa yang sanggup menjawab tentang "apa yang dimaksud dengan qodo" siswa menjawab dengan kalimat "ketentuan" interaksi di atas merupakan tanya jawab pengetahuan tentang qodho dan qodar, sebagaimana dijelaskan oleh guru bahwa "Dan sekarang apa yang dimaksud dengan qodar", tanya guru. Guru melanjutkan; ketetapan Allah, keputusan Allah disebabkan sebab akibat yang terjadi, sedang terjadi. adegan diatas sebagai pendahuluan yang berisi apersepsi dan pretest.

Komponen yang harus diperhatikan dalam proses pembelajaran adalah refleksi dari tujuan pembelajaran.

Melalui proses ini aktifitas belajar mengajar adalah memahami pengetahuan tentang akhlaq tercela dan membacakan salaah satu dali Al-Qur'an. Dalam proses pembelajaran ini guru berpedoman kepada 
kurikulum sebagaimana diungkapkan dalam silabus: "Pengertian tabzir kompetensi dasarnya menjelaskan pengertian, menjelaskan contoh, tujuan pembelajarannya menjelaskan arti ishrof, arti ghibah dan menjelaskan arti fitnah dalam kehidupan sehari-hari, dan untuk mempelajari hal ini silahkan dibaca dulu yang menjelaskan tentang ishrof yaitu Q.S. Al- An'am ayat 141 silahkan dibuka dan dibaca yah". Dapat ditarik kesimpulana sementara bahwa guru agama dalam kegiatan pembelajaran terpaku kepada petunjuk silabus yang baku.

\section{Kesimpulan}

Hasil penelitian menunjukkan bahwa: Pertama, Berdasarkan hasil analisis dari dokumen perencanaan, proses pembelajaran, dan evaluasi, bahwa kompetensi Guru Agama Islam SMA dan SMK di wilayah Ciayumajakuning, sesuai Permenneg PAN \& RB No. 16 tahun 2009, telah memenuhi Kompetensi Pedagogik, Kepribadian, Sosial, dan Profesional dengan baik.

Kedua, prosedur peningkatan kompetensi guru agama Islam SMA dan SMK di wilayah Ciayumajakuning, menggunakan instumen penilaian berupa laporan dan evaluasi penilaian kompetensi guru kelas/mata pelajaran. Permendiknas No. 16/2007. Instrumen penilaian tersebut terdiri dari empat (4) ranah kompetensi menjadi empat belas (14) kompetensi, dan dikembangkan menjadi tujuh puluh delapan (78) indikator bagi guru mata pelajaran.

\section{Ucapan Terimakasih}

Dalam kesempatan pemateri menyampaikan penghargaan dan ucapan terimakasih yang sebanyak-banyaknya kepada berbagai pihak yang dengan keikhlasannya telah memberikan jasa baik, terutama sekali disampaikan kepada :

1. H. Jamiludin Hidayat, S.Pd, M.Sc, Ketua STAI Al-Ma'arif Ciamis, yang telah memberi kesempatan untuk menjadi pemateri pada seminar peningkatan mutu dosen.

2. H. W. Anwar Sadat, S.Pd.I., M.Pd.I Ketua Lembaga Penelitian dan Pengabdiaan Masyarakat, yang mengundang untuk menjadi pemateri pada seminar peningkatan mutu dosen

3. Mugni Muhit, S.Ag, M.Ag, Pembantu Ketua I, H. Ahmad Ridla Syahida, L.c, M.Ag, Pembantu Ketua II dan Eulis Sri Rosyidatul Badriyah, S.Pd.I, M.Pd sebagai pembantu Ketua III, yang telah memfasilitasi seminar peningkatan mutu dosen.

4. Seluruh peserta seminar para dosen STAI Al-Ma'arif Ciamis yang berperan aktif menyumbangkan pikiran, motivasi dan inovasi untuk meningkatkan mutu dosen.

Akhirnya semoga gagasan ini bermanfaat bagi penulis dan untuk khazanah keilmuan khususnya disiplin ilmu pendidikan Islam.

\section{Daftar Pustaka}

Al Ghazali, (2011), Ringkasan Ihya 'Ulumuddin,

Bandung:Pn.Sinar Baru Algensindo.

Al-Imam Abu Al-Fida Ismail Ibn Katsir Ad-Dimasyqi, ( 2000), Tafsir Al-Qur'an Al-Adzim, Cairo Mesir:Muassasah Qurthubah.

Al-Uastadz Ahmad Musthafa Al-Maraghi, (1947), Tafsir Al-Maraghi, Cairo Mesir:Maktabah Musthafa Al-Halabi.

Alwasilah, A. Chaedar, (2008). Pokoknya Kualitatif, Dasar-Dasar Merancang dan Melakukan Penelitian Kualitatif, Cetakan keempat, Jakarta: PT. Dunia Pustaka jaya. 
(2007), Pokoknya Menulis, Cara Baru Menulis Dengan Metode Kolaborasi, Bandung:PT. Kiblat Buku Utama.

Anonimous, (1989), Ulndang-undang Republik Indonesia Nornor 2 Tahun 1989 Tentung Sisterm Pendidikan Nasional, Surakarta:PT. Pabelan.

Arifin Anwar, (2007), Profil Baru Guru dan Dosen Indonesia, Jakarta:Penerbit Pustaka.

Arikunto, Suharsimi, (1993), Mnajemen Pengajaran Secara Manusiawi. Jakarta; Renika cipta.

$\begin{array}{lr}\text { Penelitian } & \text { Prosedur } \\ \text { Pendekatan Politik, Jakarta: } \\ \text { Rineka Cipta. }\end{array}$

Beeby, (1967), C.E. The Quality of Educational in Indonesia, Paris:Unesco.

Bisri, Cik Hasan, (1998), Penuntun Penyusunan Rencana Penelitian dun Penulisan Skripsi, Jakarta : Logos, Jakarta, Cetakan Pertama.

Bogdan, R. Biklen, S.K., (1982), Quality Research for Education and Intruction to Theory and Methods. New York:John Willy and Sons.

Burhanuddin, (1982), Analisis Administrasi Manajemen dan Kepernimpinan Pendidikan, Jakarta:Bumi Aksara.

Castetter, William. B., (1981), The Personel Function In Educational Administration. New York:Mac Millan Publishing. C.

Combs, P.H., (1985), The Word Crices and Education. Oxford University Press.
Depdikbud, (1999), Panduan Manajemen Sekolah. Dirjen Dikdasmen; Direktorat Pendidik:an Menengah Umum.

Depdikbud., (1995), Himpunan Peraturan dan Pedoman pelaksanaan Pembinaan Kesiswaan. Bandung:Cahaya Kencana.

Djuharie, O. Setiawan, (2001), Panduan Penulisun Skripsi Tesis Disertasi, Cetakan Pertama, Bandung:YramaWidya.

Engkoswara, H, (1987), Dasar-Dasar Administrasi Pendidikan, Jakarta: Depdikbud, Dirjen Dikti PPLPTK.

(1999), Menuju Indonesia Modern 2020.

Bandung:Yayasan Amal Keluarga.

Fattah, Nanang, (2000), Manajemen Berbasis Sekolah. Bandung:Andira.

(1996), Trilogi Manajemen; Prinsip Manajemen, Analisis Manajemen dan Teknologi Administrasi. Bandung:Citra Cendekia Setia.

Gaffar, Fakry Muhammad, (1994), Visi Suatu Inovasi dalam Proses Manajemen Strategik Perguruan Tinggi, Pidato Pengukuhan Jabatan Guru Besar. Bandung:Depdikbud.

Hadisubroto, Subino, (1988), StatistikPendidikun, Bandung:Publikasi IKIP.

Hasan, Said Hamid, (2000), Pedoman Penulisan Karya Ilmiah (Laporan Buku, Makalah, Skripsi, Tesis, Disertasi), Bandung:Universitas Pendidikan Indonesia

Komaruddin, (1974), Metode Penulisan Skripsi dan Tesis, Cetakan 
Kedelapan,

Bandung:Angkasa.

Moleong, Lexy J.,(1990), Melodologi Penelitian Kuulitutif, Jakarta:Remaja Karya.

Muhadjir, Noeng, (1998), Melodologi Peneliliun Kuulilutif.

Cetakan Kedelapan, Edisi III, Yogyakarta:Rake Sarasin.

Muhammad Quraish Shihab, (2012), Tafsir Al-Misbah; Pesan, Kesan dan Keserasian Al-Qur'an, Jakarta:Lentera Hati, Cet.5.

Mulyasa, (2008), Menjadi Guru Profesional Menciptakan Pembelajaran kreatif dan Menyenangkan,

Bandung:PT, Remaja Rosdakarya.

Munawwir,Ahmad Qarson, (1997), Kamus Al Munawwir Arab Indonesia terlengkap, Surabaya:Penerbit Pustaka Progressif, Cet.4.

Nasution, S, (1996), Metode Penelitiun Naturalistik Kualitatif, Cetakan Kedua, Bandung:Tarsito.

Natawijaya, Nyoman I, (2001), Perencanaan Strategik Perguruan Tinggi Negeri, (Desertasi), Bandung:PPS UPI.

Natsir, M, (1998), Kebudayaan Islam Dalam Prespektif Sejarah, Jakarta:PT. Girimukti Pasaka.

Nawawi, Hadari, (2000) Manajemen Strategik, Organisasi non Profit Bidang

Pemerintahan.

Yogyakarta:Gadjah Mada University Press.

Nurwajah Ahmad, (2007), Tafir Ayat-Ayat Pendidikan, Hati yang Selamat Hingga Kisah Luqman, Bandung:Penerbit Marja.
Peraturan Pemerintah No. 28, (1990), Sistem Pendidikan Menengah. Jakarta:Sinar Grafika.

Pidarta, Made, (1988), Manajemen Pendidikan Indonesia. Jakarta:Bina Aksara.

Poerwadarminta, W.J, (1987), Kamus Umum Bahasa Indonesia. Jakarta:Balai Pustaka.

Quigley, Yoseph V, (1993), Vision: How Leaders Develop, It Share It and Sustain It. New York:Me Graw-Hill, Inc.

Rachmat, Mamat, (2005), Tanbih Dari Masa Ke Masa, Tasikmalaya:YSB PP Suryalaya.

Randall S. Schuler, Susan E. Jackson, (1998), Manajmen Sumber Daya Manusia, Menghadapi Abad $\mathrm{Ke}$ 21, (edisi enam), Jakarta:Erlangga.

Rohmat Mulyana, (2013), Model Pembelajaran Nilai Melalui Pendidikan Agama Islam (PAI), Cet. Pertama, Jakarta:PT Saadah Pustaka Mandiri.

Satori, Djam'an. (1999) Manajemen Berbasis Sekolah (School Based Manajemen). Basic Educaional Project. Bandung, Jawa Barat.

Siagian, ST, (1998), Manajemen Strategik, Jakarta:Bumi Aksara.

Sikula, Andrew F, (1981), Personal Administration And Human Resources Manajemen. London:John Wiley and Sons.

Simamora, Henry, (1999), Manajemen Sumber Daya Manusia, Yogyakarta: Sekolah Tinggi Ilmu Ekonomi YPKN.

Singarimbun, dkk, (1980), Metode Penelitian Survai, Cetakan Pertama, Jakarta:LP3ES. 
Soemanto, Wasty, (1982) Pengantar Operasional Administrasi. Surabaya:Usaha Nasional.

Sudarwan, (2010), Profesionalisasi dan Etika Profesi Guru, Bandung: $\mathrm{CV}$, Alpabeta.

Sudjana dan Ibrahim, (2001), Penelitian dan Penilaian Pendidikan, Cetakan kedua, Bandung : Sinar Baru Algensindo.

Sudjana, Nana, (1989), Analisis Proses Belajar Mengajar. Bandung:Aksara.

Sughanda., N, (1999), Himpunan Bahan Ceramah Pada Diklat Struktural Adum dan Spama. Bandung:PT. Parahyangan.

Supriadi, Dedi, (1977), Isu dan Agenda Pendidikan Tinggi Di Indonesia. Jakarta:Roda Jayaputra.

Suryadi, Ace, (1993), Analisis Kebijakan Pendidikan,

Bandung:Remaja Rosdakarya.

Syaefudin Udin, (2010), Pengembangan Profesi Guru, Bandung:Penerbit Alfabeta.

--------------, Perencanaan Pendidikan, Bandung:PT. Remaja Rosdakarya, 2007,

Syah, Muhibbin. (2009), Psikologi Belajar, Jakarta:PT. Raja Grafindo Persada.

\begin{tabular}{|c|c|}
\hline & $\begin{array}{lr}\quad \text { (2004), } & \text { Psikologi } \\
\text { Pendidikan } & \text { dengan } \\
\text { Pendekatan } & \text { Baru, } \\
\text { Bandung:Remaja } & \\
\text { Rosdakarya. } & \end{array}$ \\
\hline Syaikhul & Azhar, Muhammad \\
\hline & $\begin{array}{l}\text { Thanthawi, At Tafsir Al } \\
\text { Wasit li al-Qur'anil al- } \\
\text { Karim, Mesir:Dar As- } \\
\text { Sa'adah. }\end{array}$ \\
\hline
\end{tabular}

Syaiuful Sagala, (2009), Kemampuan

Profesional Guru dan

Tenaga Kependidikan, Bandung:CV. Alpabeta.
Tafsir Ahmad, (2007), Filsafat Ilmu, Mengurai ontology, Epistimologi, dan Aksiologi, Bandung : PT. Remaja. (2008), Ilmu Pendidikan dalam Perspektif Islam, Bandung:PT. Remaja. Wahidin, (2015), Sains dan Agama:Rekonstruksi Integrasi Keduanya, Yogyakarta:Pn. Ombak 